\title{
MOVING FORWARD WITH HEALTH SURVEYS: A REPORT OF THE 2001 CATI FORUM
}

Tricia Fox and Margo Eyeson-Annan

NSW Health Survey Program

NSW Department of Health

In any discussion of health surveys, the central role of the interviewer in data collection is sometimes overlooked. But at the 2001 Computer Assisted Telephone Interviewing (CATI) Forum, interviewers from the NSW Health Survey Program took centre stage, with two powerful performances revealing the mysteries, methods, and madness of conducting CATI health survey interviews.

The 2001 Computer Assisted Telephone Interviewing (CATI) Forum, held in Sydney in November 2001 at the Powerhouse Museum, was convened by the National CATI Technical Reference Group (a sub-committee of the National Public Health Information Working Group) and sponsored by the Commonwealth Department of Health and Ageing and the NSW Department of Health. Delegates came from across Australia to hear speakers from the World Health Organization, Health Canada, state and territory health departments, the Commonwealth Department of Health and Ageing, the Australian Bureau of Statistics, the Australian Institute of Health and Welfare, and other research groups.
The first day was dedicated to an examination of the measurement of inequalities in health through health surveys, and how health survey data can influence policy. The second day explored methodological issues such as sampling, validation, pre-testing, question development, data collection, automated reporting, and the applications of survey data.

The messages from the Forum include the need for harmonisation of CATI questions among states and territories, the need for trend data, and aligning survey information in order to influence policy.

A subsequent meeting of representatives from each of the states undertaking CATI health surveys was held in Adelaide on 10 December 2001, to seek consensus on a minimum set of questions for SNAPS topic areas (Smoking, Nutrition, Alcohol, Physical Activity, and Mental Health). This was achieved, along with progress on minimum sets of questions for demographics, asthma, and diabetes. These questions have already been incorporated into the NSW Health Survey Program, which commenced yearround interviewing (as distinct from a series of discrete surveys) in February 2002.

\section{COMMUNICABLE DISEASES, NSW: APRIL 2002}

\section{TRENDS}

Notifications of communicable diseases received by NSW Health through to February 2002 are shown in Table 5 and Figure 2. Notably, there have been relatively few reports of Ross River virus infection this season, although Barmah Forest virus infection remained active in the mid North coast. Both these infections are due to arboviruses that are transmitted through the bite of infected mosquitos, and which can cause a self-limiting illness characterised by rash, fever, and joint pains. Reports of cryptosporidiosis remain relatively high, especially in rural areas (although well below the epidemic levels seen in 1998 linked to swimming in contaminated swimming pools). No common source of disease linked to an outbreak has been identified this summer. Relatively few reports of meningococcal disease were received over the summer months; and, for the fourth month running, no cases of measles were reported in NSW.

\section{SALMONELLOSIS OUTBREAK}

Salmonellosis is an acute illness caused by infection with Salmonella bacteria. It is characterised by a sudden onset of headache, abdominal pain, diarrhoea, nausea, and vomiting.

There are several species of Salmonella bacteria, the most common of which is Salmonella typhimurium. Salmonella typhimurium can be further subgrouped by phage typing. In the past Salmonella typhimurium phage type 9 (STMPT9) infections were relatively common in NSW; although in 2001 cases were reported less frequently.

Chickens, cattle, and other animals are natural reservoirs of Salmonella bacteria. Salmonellosis is transmitted via the faecal-oral route, usually through eating contaminated food, but sometimes from person-to-person, or from animal-to-person. It is postulated that many infections are acquired when contaminated foods (like chicken) are not cooked sufficiently to kill the bacteria, or when they are handled in a way that allows cross-contamination with other foods that are not cooked further. Changes in the type of Salmonella bacteria found in chickens may lead to changes in the type of salmonella bacteria subsequently infecting people via the food chain.

In February, an increase in STMPT9 was identified. To date, 82 cases have been reported with onset in 2002 , 
compared with 126 for the whole of 2001 . There were 55 cases reported with onset in February 2002, compared with only 16 in February 2001 (Figure 1).

Compared with all cases of salmonellosis identified in 2001, a higher proportion of the 82 STMPT9 cases identified in 2002 were females, and a lower proportion were less than five years old. In both years, STMPT9 cases occurred more frequently in the Sydney area (Table 1).

Two clusters have been identified among the STMPT9 cases reported in February 2002. The first cluster involved seven cases who were students of a Northern Sydney boarding school. The Northern Sydney Public Health Unit (NSPHU) investigated this outbreak and identified a total of 105 students who reported gastrointestinal disease between 11 and 22 February. These cases were also likely to be caused by STMPT9. NSPHU conducted a casecontrol study involving both ill and well students, but the sources of infection remain unclear.
The second cluster of cases was among people who had eaten at a restaurant in Western Sydney. In late February, Western Sydney Public Health Unit (WSPHU) received a report that a group of people who had eaten at the restaurant had become ill with gastroenteritis. WSPHU staff subsequently interviewed 19 people who were at the restaurant on 20 and 21 February. Of these, eight reported illness within 48 hours of eating there (in two of these individuals, STMPT9 infection was confirmed on stool testing). In a retrospective cohort study, WSPHU found an association between illness and eating deep fried ice cream. Investigation revealed that the ice cream had been battered using a tray that had earlier been used to prepare raw chicken. This practice has since ceased.

Staff from the NSW Department of Health interviewed 37 other STMPT9 cases; seven of these reported eating at the same restaurant. All seven reported eating the restaurant's deep fried ice cream between 7 and 22 February.

\begin{tabular}{|c|c|c|c|c|}
\hline \multicolumn{5}{|c|}{$\begin{array}{l}\text { CHARACTERISTICS OF PEOPLE REPORTED WITH SALMONELLA TYPHIMURIUN } \\
\text { PHAGE TYPE } 9 \text { (STMPT9), AND OTHER TYPES OF SALMONELLOSIS, EXPRESSED AS } \\
\text { NUMBERS AND PERCENTAGES, NSW, JANUARY } 1997 \text { TO FEBRUARY } 2002\end{array}$} \\
\hline \multirow{2}{*}{$\begin{array}{l}\text { Case } \\
\text { characteristics }\end{array}$} & \multicolumn{2}{|c|}{ Jan-Dec 2001} & \multicolumn{2}{|c|}{ Jan-Feb 2002} \\
\hline & $\begin{array}{r}\text { STMPT9 } \\
\boldsymbol{N} \% \\
\end{array}$ & $\begin{array}{l}\text { Other } \\
N \quad \%\end{array}$ & $\begin{array}{c}\text { STMPT9 } \\
\boldsymbol{N} \% \\
\end{array}$ & $\begin{array}{l}\text { Other } \\
N \quad \%\end{array}$ \\
\hline Male & 67 (53) & $780(51)$ & 32 (39) & $230(51)$ \\
\hline$<5$ & 43 (34) & 470 (31) & $18(22)$ & 124 (27) \\
\hline $5-24$ & $47(37)$ & $400(26)$ & $32(39)$ & $144(32)$ \\
\hline $25-64$ & $31(25)$ & $563(37)$ & $25(30)$ & 149 (33) \\
\hline $65+$ & $5(4)$ & $106(7)$ & $7(9)$ & 34 ( 8) \\
\hline Rural & $31(25)$ & $674(44)$ & $14(17)$ & $220(49)$ \\
\hline Total & $126(100)$ & $1539(100)$ & $82(100)$ & $451(100)$ \\
\hline
\end{tabular}

\section{FIGURE 1}

REPORTS OF SALMONELLA TYPHIMURIUN PHAGE TYPE 9 (STMPT9), AND OTHER TYPES OF SALMONELLOSIS, BY MONTH OF ONSET, NSW, JANUARY 1997 TO FEBRUARY 2002

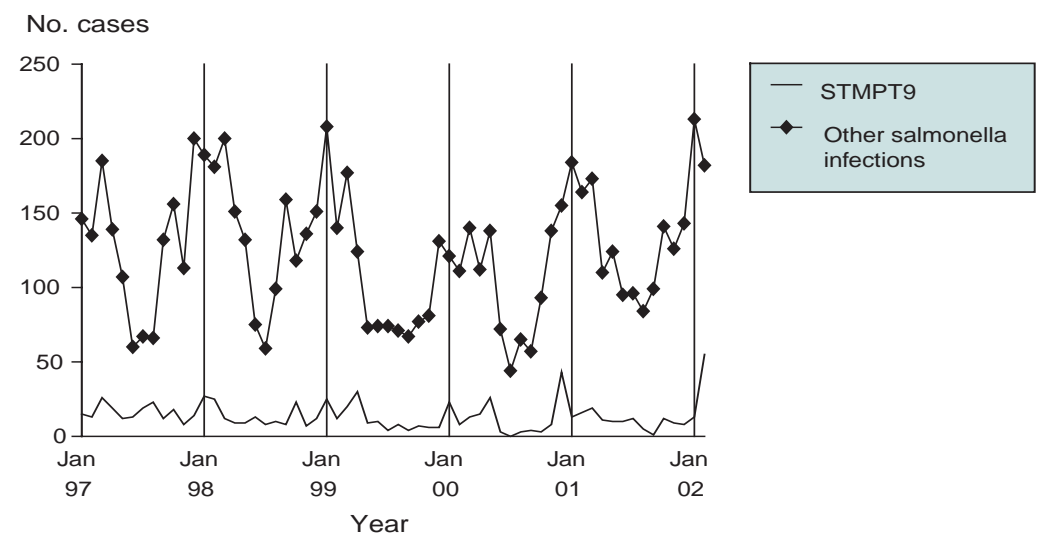




\section{QUARTERLY REPORT: AUSTRALIAN CHILDHOOD IMMUNISATION REGISTER}

Table 2 reports immunisation coverage by area health service for children aged 12 months to less than 15 months.

These data refer to four different cohorts of children whose age has been calculated 90 days before data extraction. The information contained in each of the reports has been extracted from the Australian Childhood Immunisation Register (ACIR) and may not reflect true levels of coverage due to under-reporting. The percentages of children in each area health service who are fully vaccinated for this age is presented according to the current immunisation schedule.

\section{TABLE 2}

PERCENTAGE OF IMMUNISATION COVERAGE BY AREA HEALTH SERVICE FOR CHILDREN AGED 12 MONTHS TO LESS THAN 15 MONTHS

\begin{tabular}{|c|c|c|c|c|}
\hline $\begin{array}{l}\text { Area health } \\
\text { service }\end{array}$ & $\begin{array}{c}30 \\
\text { June } \\
2001\end{array}$ & $\begin{array}{c}30 \\
\text { Sept } \\
2001\end{array}$ & $\begin{array}{c}31 \\
\text { Dec } \\
2001\end{array}$ & $\begin{array}{c}31 \\
\text { March } \\
2002\end{array}$ \\
\hline Central Coast & 94 & 93 & 94 & 92 \\
\hline Central Sydney & 91 & 89 & 87 & 88 \\
\hline Hunter & 94 & 96 & 93 & 94 \\
\hline Illawarra & 92 & 93 & 91 & 93 \\
\hline Northern Sydney & 90 & 89 & 89 & 90 \\
\hline South Eastern Sydney & 89 & 89 & 89 & 90 \\
\hline South Western Sydney & 92 & 90 & 89 & 90 \\
\hline Wentworth & 92 & 92 & 91 & 92 \\
\hline Western Sydney & 89 & 90 & 89 & 90 \\
\hline Far West & 87 & 92 & 94 & 92 \\
\hline Greater Murray & 93 & 93 & 93 & 93 \\
\hline Macquarie & 93 & 92 & 95 & 92 \\
\hline Mid North Coast & 91 & 91 & 88 & 90 \\
\hline Mid Western & 90 & 92 & 92 & 92 \\
\hline New England & 92 & 92 & 94 & 94 \\
\hline Northern Rivers & 86 & 86 & 84 & 80 \\
\hline Southern & 91 & 91 & 89 & 93 \\
\hline NSW & 91 & 91 & 91 & 91 \\
\hline
\end{tabular}

\section{QUARTERLY REPORT: HIV NOTIFICATIONSTO END OF DECEMBER 2001}

To the end of December 2001, the cumulative number of HIV diagnoses in NSW residents was 12,450. The number of new diagnoses of HIV in NSW has plateaued over the past few years, and was 360 in 2001 (Tables 3 and 4).

Between 1981 and 2001, 92 per cent of NSW residents diagnosed with HIV infection were males and 89 per cent were 20-49 years of age. Reported exposures included male-to-male sexual contact (with or without a history of injecting drug use) in over 60 per cent of cases, injecting drug use for three per cent of cases, and heterosexual contact (as the only risk factor) for seven per cent of cases. For over a quarter ( 27 per cent) of all notifications, no risk factor was reported. However, over the period 1991-2000, the proportion of notifications with undetermined or unknown risk factor information declined to 16 per cent.
In 2001,88 per cent of cases were males and 86 per cent were 20-49 years of age. Male-to-male sexual contact (with or without a history of injecting drug use) was reported for 59 per cent of cases, injecting drug use for five per cent of cases, and heterosexual contact (as the only risk factor) for 15 per cent of cases. The proportion of cases with undetermined or unreported risk factors was 17 per cent. Some of these notifications may be duplicated. The Communicable Diseases Branch is currently undertaking active follow-up of these notifications.

\section{AIDS diagnoses and AIDS deaths}

The cumulative AIDS diagnoses and AIDS deaths to December 2001 were 4888 and 3330 respectively. The number of diagnoses and deaths declined significantly in 2001 falling from 115 and 69 respectively in 2000, to 62 and 33 respectively in 2001 .

While data from recent years may be under-reported, they indicate that there have been reductions in the number of people being diagnosed with and dying from AIDS in NSW.

While there has been a decline in the rate of new cases of HIV infection overall, there is a growing number of people living with HIV infection in NSW. Consequently, it is essential that HIV prevention efforts continue to be a priority.

\section{TABLE 3}

NOTIFICATIONS OF HIV, AIDS, AND AIDS DEATHS, REPORTED BYYEAR, NSW, 1981-2001

\begin{tabular}{|c|c|c|c|}
\hline Year & HIV & AIDS & AIDS Deaths \\
\hline 1981 & 1 & 1 & 1 \\
\hline 1982 & 1 & 1 & 0 \\
\hline 1983 & 1 & 3 & 1 \\
\hline 1984 & 202 & 30 & 6 \\
\hline 1985 & 990 & 91 & 46 \\
\hline 1986 & 1110 & 160 & 108 \\
\hline 1987 & 1635 & 250 & 143 \\
\hline 1988 & 1144 & 312 & 138 \\
\hline 1989 & 988 & 346 & 235 \\
\hline 1990 & 813 & 417 & 313 \\
\hline 1991 & 810 & 435 & 334 \\
\hline 1992 & 708 & 415 & 304 \\
\hline 1993 & 597 & 464 & 363 \\
\hline 1994 & 506 & 520 & 405 \\
\hline 1995 & 539 & 454 & 339 \\
\hline 1996 & 459 & 348 & 255 \\
\hline 1997 & 426 & 194 & 108 \\
\hline 1998 & 409 & 165 & 68 \\
\hline 1999 & 390 & 105 & 61 \\
\hline 2000 & 359 & 115 & 69 \\
\hline 2001 & 360 & 62 & 33 \\
\hline Jan'01-Mar'01 & 86 & 12 & 6 \\
\hline Apr'01-Jun'01 & 88 & 16 & 4 \\
\hline Jul'01-Sep'01 & 103 & 20 & 13 \\
\hline Oct'01-Dec'01 & 83 & 14 & 10 \\
\hline Total & 12450 & 4888 & 3330 \\
\hline
\end{tabular}




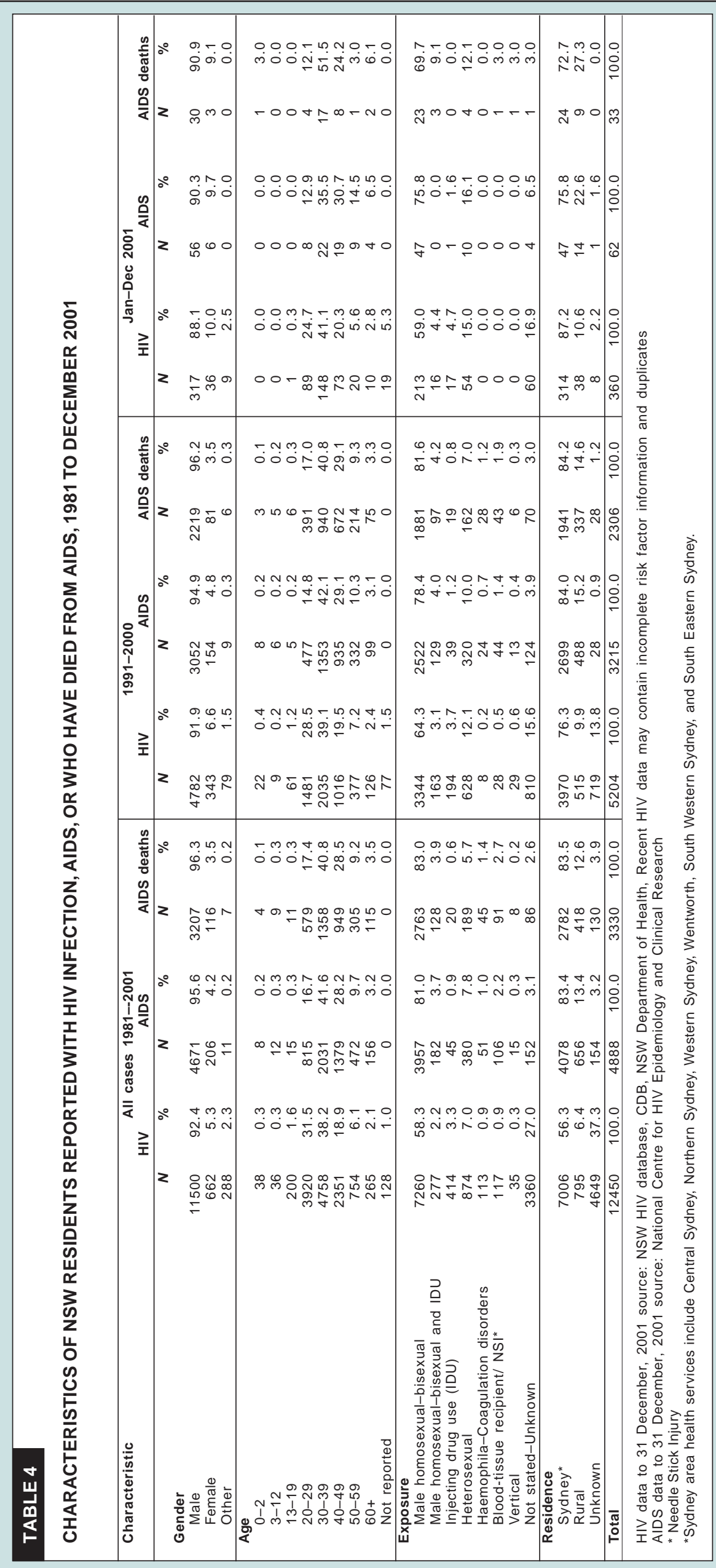




\section{FIGURE 2}

\section{REPORTS OF SELECTED COMMUNICABLE DISEASES, NSW, JANUARY 1997 TO FEBRUARY 2002, BY MONTH OF ONSET}

These are preliminary data: case counts for recent months may increase because of reporting delays. Laboratory-confirmed cases, except for measles, meningococcal disease and pertussis actual _ _ _ predicted after adjusting for likely reporting delays.

\begin{tabular}{|rc|}
\hline \multicolumn{2}{|c|}{ NSW population } \\
Male & $50 \%$ \\
$<5$ & $7 \%$ \\
$5-24$ & $28 \%$ \\
$25-64$ & $52 \%$ \\
$65+$ & $13 \%$ \\
Rural $^{*}$ & $42 \%$ \\
\hline
\end{tabular}
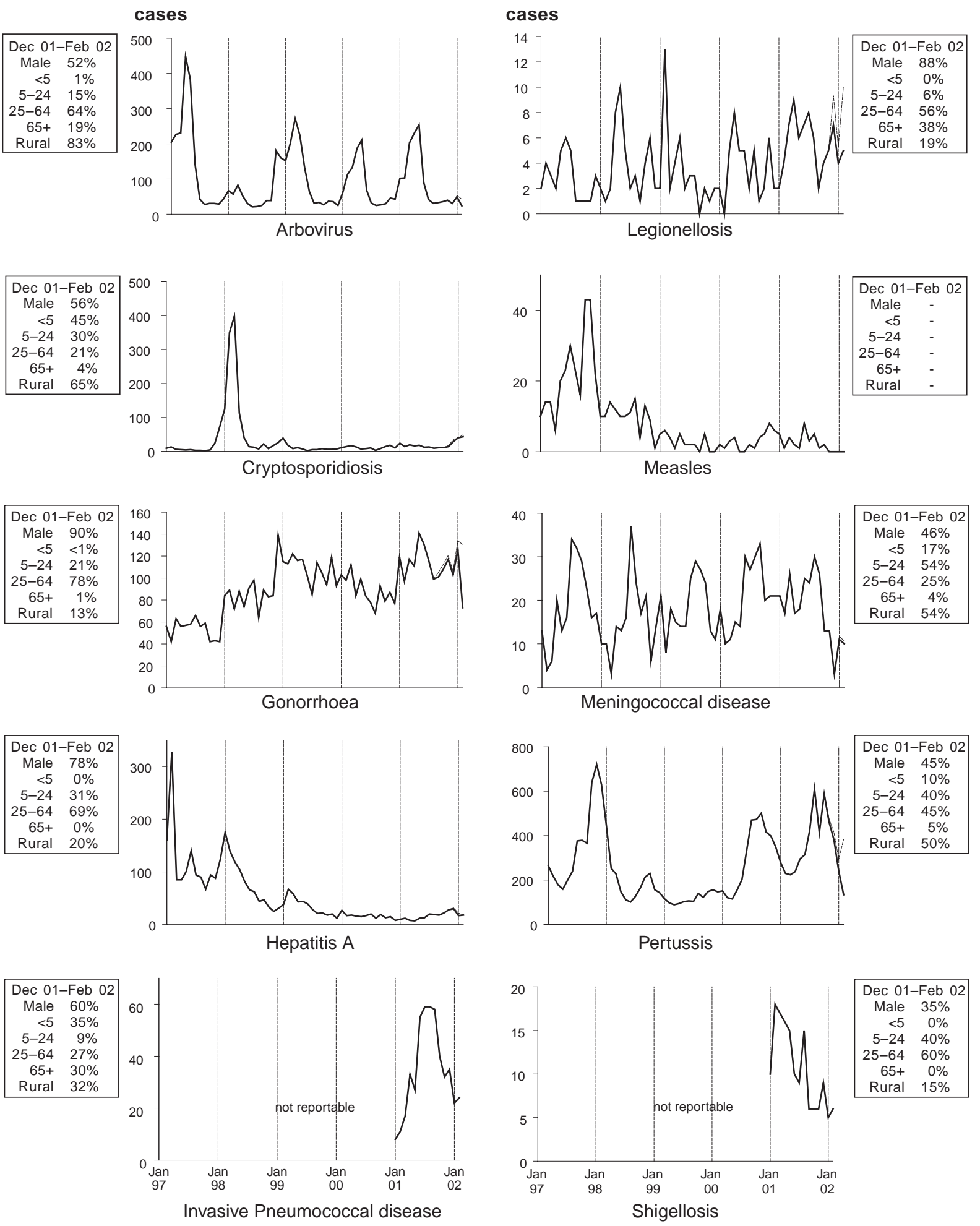

* For definition, see NSW Public Health Bulletin, April 2000 


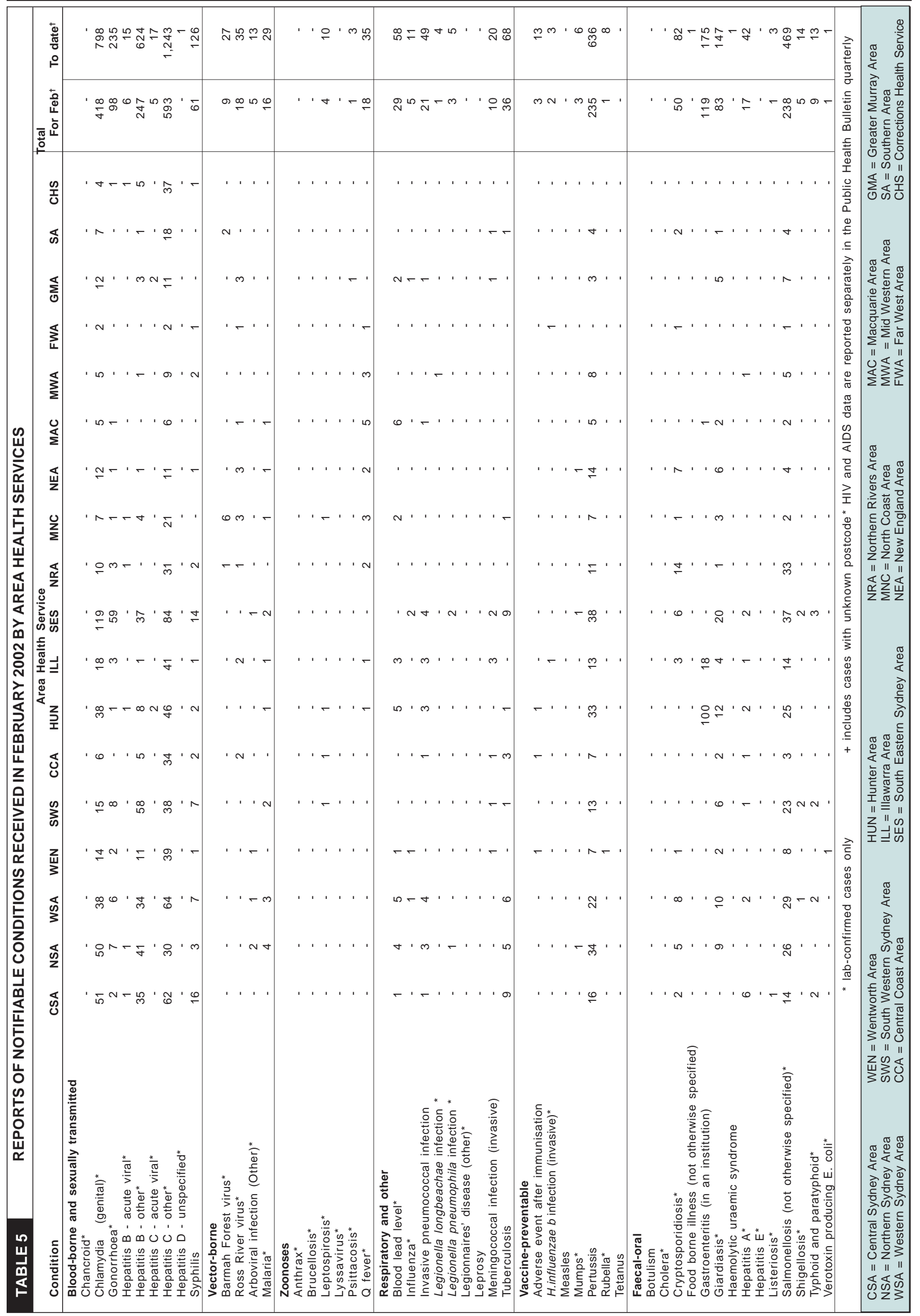

